\title{
Does Mechanical Screening of Contaminated Forest Fuels Improve Ash Chemistry for Thermal Conversion?
}

\author{
Marjan Bozaghian Bäckman, Anna Strandberg, Mikael Thyrel, Dan Bergström, and Sylvia H. Larsson*
}

Cite This: Energy Fuels 2020, 34, 16294-16301

Read Online

ABSTRACT: The effect of mechanical screening of severely contaminated forest fuel chips was investigated, focusing on main ashforming elements and slagging tendency and other properties with relevance for thermal conversion. In this study, screening operations were performed according to practice on an industrial scale by combining a star screen and a supplementary windshifter in six different settings and combinations. Mechanical screening reduced the amount of ash and fine particles in the accept fraction. However, the mass losses for the different screening operations were substantial (20-50 wt \%). Fuel analyses of the non-screened and the screened fuels showed that the most significant screening effect was a reduction of $\mathrm{Si}$ and $\mathrm{Al}$, indicating an effective removal of sand and soil contaminations. However, the tested fuel's main ash-forming element's relative concentration did not indicate any improved combustion characteristics and ash-melting behavior. Samples of the accept fractions and non-screened material were combusted in a single-pellet thermogravimetric reactor, and the resulting ashes' morphology and elemental composition were analyzed by scanning electron microscopy-energy dispersive X-ray spectrometry and the crystalline phases by powder X-ray diffraction. Results from both these analyses confirmed that screening operations had no, or minor, effects on the fuels' ash chemistry and slagging tendencies, i.e., the fuels' proneness to ash melting was not improved. However, the reduction of ash and fine particles can reduce slagging and other operational problems in smaller and more sensitive combustion units.

\section{INTRODUCTION}

More than half of the land area in Sweden is covered by forest (23.2 million hectares), and this resource constitutes an important source of European biomass. ${ }^{1}$ Forest-derived fuel is often categorized according to the origin and processing method; sawdust, cutting shavings, chips, and bark are industrial byproducts while logging residues, also called forest fuels (e.g., branches and tops, small trees, and low-quality tree stems without forest-industrial use), are byproducts of forest operations. The potential of primary forest fuels (byproducts from forest operations) that economically can be extracted from Swedish forestry is estimated to be $640 \mathrm{TWh} .^{2}$ In 2013, the total supply of primary forest fuels in Sweden was $\sim 30$ TWh, which in 2017 decreased to $\sim 26$ TWh. $^{3}$ Despite logistical challenges of low energy density and fuel composition, there is a great potential for increased usage of this biomass assortment. ${ }^{4,5}$

Contrary to large-scale heating plants (>50 MW), smallscale district heating plants $(<1 \mathrm{MW})$ represent a specific market sector that imposes tighter fuel quality specifications due to being more sensitive to fuel quality variation (moisture content, ash content, particle size, heating value, and extrinsic contaminations such as clay and sand minerals). ${ }^{6-9}$ For smalland medium-scale applications, wood chips' fuel quality requirements are graded according to international standards (ISO 17225-4) ${ }^{10}$ into different quality classes, A1 or A2, where A1 has a higher quality, e.g., lower moisture and ash content compared to class A2. Looking at the ISO guidelines (ISO 17225-4), stored logging residue chips seldom fulfill the highquality class' demands.
In practice, screening of wood chip fuels is applied to decrease the fine and oversized particle amounts and reduce ash content, thereby decreasing operational problems. Several operational screening methods are useful to improve fuel quality. ${ }^{6,11-14}$ The overall aim of screening is to reduce the amount of oversized and fine particles. Oversized particles affect fuel flowability and handling properties, which may hinder fuel transportation in conveying ducts and cause bridging of fuels inside storage rooms. ${ }^{15,16}$ Fine particle fractions often contain higher amounts of impurities (sand and soil minerals), increasing ash content and the risk of ashrelated operational problems such as slagging and fouling., ${ }^{4,17}$ In addition, fine particle fractions might cause unfavorable combustion conditions due to the uneven flow of combustion air through the fuel bed, thereby increasing emissions of gas and particles. ${ }^{18,19}$

Forest fuels have higher ash content than stemwood residues (such as sawdust and wood pellets), and the main ash-forming elements are $\mathrm{Si}, \mathrm{Ca}, \mathrm{Mg}, \mathrm{K}, \mathrm{Na}, \mathrm{P}, \mathrm{S}, \mathrm{Cl}, \mathrm{Al}, \mathrm{Fe}$, and $\mathrm{Mn}$, to a varying degree between stem, bark, branches, shoots, and foliage. $^{20-22}$ Ash-forming elements are either inherent or present in sand and soil minerals introduced in harvesting and handling processes (extrinsic material). ${ }^{23}$ During combustion,

Received: September 22, 2020

Revised: October 26, 2020

Published: November 17, 2020

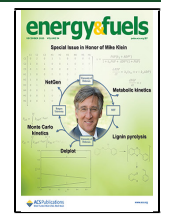


the inherent ash-forming elements in the biomass are usually more reactive than those originating from the extrinsic material. $^{20,24}$

Alkali ( $\mathrm{K}$ and $\mathrm{Na}$ ) is one of the biggest issues from a combustion perspective. Alkali can react with, e.g., $\mathrm{Cl}$ or $\mathrm{S}$, to form sticky low-melting alkali salts, which can lead to fouling and corrosion and formation of fine particles $\left(\mathrm{PM}_{1}\right)^{25-29}$ Another large issue is alkali forming low-melting alkali silicates, leading to slag formation in bottom ash. ${ }^{29}$ A previous research demonstrates that volatile ash-forming elements, such as alkali, can be captured in the fuel silicate matrix and extrinsic silicate compounds with relatively high melting temperatures, ${ }^{30}$ and $\mathrm{K}$ is increasingly retained in bottom ash with fuel with higher $\mathrm{Si}$ content. $^{31} \mathrm{~A}$ high concentration of $\mathrm{Ca}$ in the fuel can inhibit slag from these low-melting silicates by forming $\mathrm{Ca}$ silicates with higher melting temperatures. ${ }^{32-35}$ Stored forest residue chips with a high content of extrinsic sand and soil minerals result in fuel with higher Si content than non-contaminated fuels. Extrinsic Si will mainly provide solid particle surface interactions unless long residence times and high temperatures prevail. $^{20,25}$ However, despite the lower relative proportion of reactive inherent $\mathrm{Si}$, higher overall $\mathrm{Si}$ content can increase the risk of slag formation by reducing ash-melting temperatures when forming low-melting alkali silicates. ${ }^{4,5,36}$

Little is known about how the generally applied screening actions at fuel production affect the fuels' ash composition and ash-related combustion properties. In one study, Zeng et al. ${ }^{31}$ investigated the risk of bottom ash slagging and high pollutant emission levels in small-scale boilers during the combustion of wood chips, which had undergone different drying and sieving process steps for the removal of adhering soil and other extraneous impurities. The fuel processing decreased the calculated theoretical risk for bottom ash slagging, but due to low combustion temperature, no formation of agglomerates in the bottom ash was observed.

This study's primary purpose was to investigate whether industrially applied screening methods used to improve forest residues' fuel quality also affect the fuels' ash chemistry. Specific goals were to

- for stored forest residue chips, determine the effects of different mechanical screening settings on the accept fraction's (particle size: $3-45 \mathrm{~mm}$ ) fuel properties: ash content, moisture content, and calorific value;

- quantify the mass loss from different screening operations;

- by thermogravimetric analysis (TGA) in a single-pellet scale, evaluate the combustion performance of the different screened and un-screened fuels;

- evaluate the composition and morphology of the fuel ashes and determine the influence of screening on residual ash phases; and

- determine if mechanical screening is valid for improving the ash chemistry and reducing the risk of ash-related operational problems in combustion appliances.

\section{MATERIALS AND METHODS}

Crushed logging residue chips had been stored for 5 months at the fuel yard of a CHP plant (Dåva, Umeå Energi, Umeå, Sweden) and were delivered to the Biomass Technology Centre, Swedish University of Agricultural Sciences, Umeå, Sweden. The logging residues had several suppliers, and no data was available for the tree species or tree-part composition. However, the general species distribution at local logging sites (see Table 4 in ref 23) is an average of ca. $60 \%$ of Norway spruce, $20 \%$ of Scots pine, $15 \%$ of birch, and $5 \%$ of other broadleaf species.

Material Preparation. A mobile star screen (Backer 3-mal, Backers Maschinenbau GmbH, Twist, Germany) with two screens, 3 and $45 \mathrm{~mm}$, was used to separate the forest fuel chips into three fractions. The medium fraction $(3-45 \mathrm{~mm})$, denoted accept, which, in practice, would be the fraction utilized as fuel for the thermal conversion, was further studied. The other fractions (fine $(<3 \mathrm{~mm})$ and coarse $(>45 \mathrm{~mm})$ ) were discarded. In an industrial case, the oversized fraction can be recycled after an extra step of comminution before fractioning, but this was not feasible in this study. Also, the share of oversized material was minor: $1.5-3.5 \%$ (Table 2 ).

The effects of the fine deck stars' rotation speed were determined by star screening at three different rotation speeds: 80,90 , and $100 \%$ of the maximum capacity (corresponding to 120,158 , and $170 \mathrm{rpm}$, respectively) when the feeder was run at $80 \%$ of its maximum capacity. These settings were denoted M80, M90, and M100. The effects of using a supplementary windshifter (Norditek VS1200, Norditek, Sävar, Sweden), which provided more efficient removal of high-density contaminants (e.g., stones, gravel, and sand minerals), were determined by screening accept fractions from the M80, M90, and M100 treatments. However, in this case, the star screening was performed at $61 \%$ of the feeder's maximum capacity. These settings were denoted MW80, MW90, and MW100. The lower feeding rate was due to limitations in the windshifter's capacity. On average, 2.4 metric tons $(t)$ of wood chips was screened at each machine setting (Table 1). Samples $(10 \mathrm{~L}$ each) were taken in triplicates from the

Table 1. Screen Settings $(M=$ Only Star Screen, $M W=$ Star Screen + Windshifter)

$\begin{array}{lccc}\begin{array}{l}\text { screen } \\ \text { setting }\end{array} & \begin{array}{c}\text { rotation speed of the stars in } \\ \text { the fine deck (\% of the } \\ \text { maximum speed) }\end{array} & \begin{array}{c}\text { speed of the feeder } \\ \text { (\% of the } \\ \text { maximum speed) }\end{array} & \text { windshifter } \\ \text { NS } & \text { N/A } & \text { N/A } & \text { no } \\ \text { M100 } & 100 & 80 & \text { no } \\ \text { M90 } & 90 & 80 & \text { no } \\ \text { M80 } & 80 & 80 & \text { no } \\ \text { MW100 } & 100 & 61 & \text { yes } \\ \text { MW90 } & 90 & 61 & \text { yes } \\ \text { MW80 } & 80 & 60 & \text { yes }\end{array}$

falling stream for the subsequent fuel analyses and combustion experiments. After screening, each size fraction was weighed, and the relative mass distribution was determined (Table 2). The initial non-

Table 2. Mass Fractions (\% on Wet Basis) of Accepts, Fines, and Over-Sized Particles after Separation by Different Screening Settings ${ }^{a}$

\begin{tabular}{lrrrrrr}
\multicolumn{1}{c}{ fraction } & M100 & M90 & M80 & MW100 & MW90 & MW80 \\
accept $(3-45 \mathrm{~mm})$ & 81.0 & 69.6 & 66.6 & 65.6 & 56.7 & 50.6 \\
fines $(<3 \mathrm{~mm})$ & 15.5 & 28.7 & 31.7 & 31.3 & 41.7 & 47.9 \\
over-sized $(>45 \mathrm{~mm})$ & 3.5 & 1.7 & 1.7 & 1.6 & 1.6 & 1.5 \\
${ }^{a} \mathrm{M}=$ only star screen, MW $=$ & star screen + windshifter. \\
\hline
\end{tabular}

screened material denoted "non-screened (NS)" was, before the screening operations, systematically sampled from multiple positions in the raw material pile. Fuel and combustion properties were determined for the accept fractions and the non-screened material.

Samples of each assortment were mixed and reduced with a sample divider, dried at $105^{\circ} \mathrm{C}$ for $16 \mathrm{~h}$, and then milled in a cutting mill (1 $\mathrm{mm}$ screen size). For TGA combustion analyses, eight pellets from each of the seven assortments were produced in an in-house singlepellet press according to a pelletizing procedure ${ }^{37}$ that mimics true ring die pellet production.

Fuel Analyses. Standard fuel analyses were performed by an accredited lab on non-screened material and the accept fractions from 
the different screening settings. The moisture content was determined at $105{ }^{\circ} \mathrm{C}$ according to ISO 18134 , ash content at $550{ }^{\circ} \mathrm{C}$ according to standard ash content determination ISO 18122:2015, and the calorific value by SS-EN ISO 18125. The fuel ash composition was determined by inductively coupled plasma-atomic emission spectroscopy (ICP-AES), according to SS-EN 13656.

Combustion Experiments: Macro-TGA. Combustion experiments were conducted in an in-house constructed, laboratory-scale, single-pellet TGA reactor at TEC-lab, Umea University, Sweden. The reactor consisted of a furnace with internal dimensions of $200 \times 130$ $\times 130 \mathrm{~mm}$ and a quenching tower separated from the furnace zone by a sliding hatch to enable the use of different atmospheres (Figure 1).

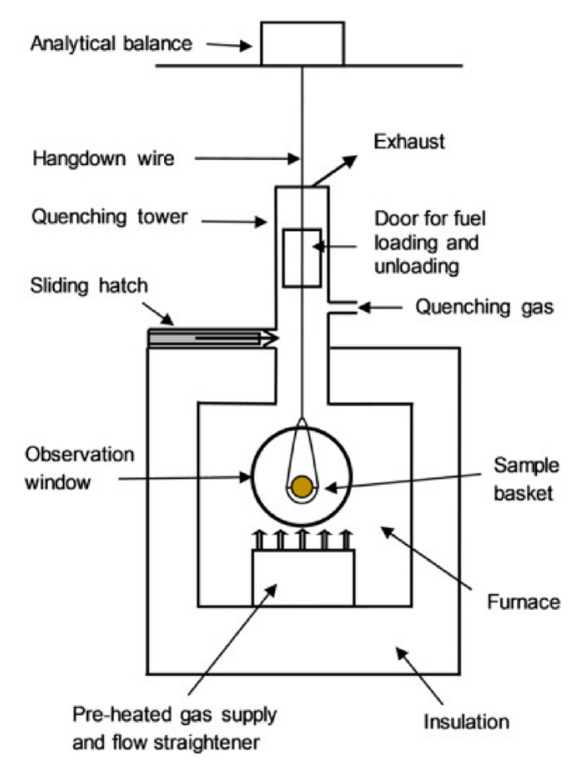

Figure 1. Schematic image of the used single-pellet reactor. Reprinted from ref 38. Copyright 2018 Elsevier.

Electrical wall heaters heated the furnace, and the furnace temperature was set to $850{ }^{\circ} \mathrm{C}$. Although the operating furnace temperature was set to $850{ }^{\circ} \mathrm{C}$ for all experiments, data from a study performed in the same single-pellet reactor by Fagerström et al. ${ }^{28}$ showed that the actual pellet temperature during combustion was approximately 200 ${ }^{\circ} \mathrm{C}$ higher. Consequently, the maximum temperature inside the pellets in this study can be assumed above $1000{ }^{\circ} \mathrm{C}$. Pre-heated dry air was supplied to the bottom of the furnace $(15 \mathrm{~L} / \mathrm{min})$, and $\mathrm{N}_{2}$ gas $(3 \mathrm{~L} /$ min) was supplied to the quenching tower. The samples were placed in a combustion or quenching position by moving the reactor vertically using a pneumatic cylinder underneath the reactor. Also, a window on the furnace's front side was used to observe the fuel conversion visually. In each experiment, one pellet was placed in a platinum mesh basket connected to an analytical balance with a resolution of $1 \mathrm{mg}$. Each pellet was cut to length to obtain a weight of $800 \mathrm{mg}$, with 1 wt $\%$ dry basis precision. After completed char combustion, at the end of the glowing char phase with no further mass loss, the sample was kept in the furnace for $30 \mathrm{~s}$ before the furnace was lowered, and the residual ash was allowed to cool down in a $\mathrm{N}_{2}$ atmosphere. After cooling, the sample basket was removed, and the residual ash was weighed.

Sample Preparation and Analysis. Sample morphology was analyzed by variable-pressure scanning electron microscopy (VPSEM; Carl Zeiss Evo) using backscattered electron detectors at an accelerating $20 \mathrm{kV}$ voltage and probe current of $500 \mathrm{pA}$. The residual ash samples (not mortared) were transferred to double-sided carbon tapes before analysis. Elemental analysis was performed on mortared samples with an energy dispersive X-ray spectrometer (EDS; Oxford Instruments X-Max with an $80 \mathrm{~mm}^{2}$ detector area) at an accelerating $20 \mathrm{kV}$ voltage and probe current of $500 \mathrm{pA}$. The residual ashes' elemental composition was determined by area analyses $(1.5 \times 1.1$ $\mathrm{mm}$ ) in triplicates for each ash fraction and with four analyses per triplicate, resulting in 12 areas.

Powder X-ray diffraction (XRD) analysis was performed on mortared samples for crystalline phase identification using a Bruker AXS D8 Advance with $\mathrm{CuK} \alpha$ radiation fitted with a Vantec- 1 detector operated in $2 \theta$ mode $10-70^{\circ}$ with a continuously spinning sample. Collected diffractograms were evaluated with the PDF-4 database in Diffrac EVA 5.X; ${ }^{39}$ the semi-quantitative analysis of relative concentrations of compounds was performed using Rietveld refinement in TOPAS 4.2.

\section{RESULTS}

Fuel Properties of Screened Fractions. Screening demonstrated a separation of size fractions by removing fine and coarse particles from the desired accept fraction (Table 2). Depending on the star screen settings, fine (15.6-47.4 wt \%) and coarse $(1.5-3.5 \mathrm{wt} \%)$ particles were separated from the accept fraction. The star screen's slower rotational speed resulted in a higher separation of fines, giving higher fuel mass loss. Windshifting further increased the removal of fines, resulting in even greater fuel mass loss. Screening resulted in reduced ash and moisture content and increased the higher heating value (HHV) (Table 3). Star screening with the lowest

Table 3. Ash Content (\%), Moisture Content (\%), and Higher Heating Value (HHV; $\mathrm{MJ} / \mathrm{kg}$ d.b.) in the NonScreened Material and the Accept Fractions ( $M=$ Only Star Screen, MW = Star Screen + Windshifting) Presented as Mean Values of 3 Replicates, Except for the HHV that was Based on One Sample, Hence No Std is Presented

\begin{tabular}{lccccc}
$\begin{array}{l}\text { screen } \\
\text { setting }\end{array}$ & $\begin{array}{c}\text { ash content } \\
(\%)\end{array}$ & std & $\begin{array}{c}\text { moisture } \\
\text { content }(\%)\end{array}$ & std & $\begin{array}{c}\mathrm{HHV}(\mathrm{MJ} / \mathrm{kg} \\
\text { d.b. })\end{array}$ \\
$\begin{array}{l}\text { non- } \\
\text { screened }\end{array}$ & 11 & 1.4 & 63 & 1.5 & 17.4 \\
M100 & 8.8 & 0.4 & 62 & 0.6 & 17.7 \\
M90 & 7.1 & 0.3 & 62 & 1.2 & 18.7 \\
M80 & 7.2 & 1.1 & 59 & 1.0 & 18.6 \\
MW100 & 6.3 & 0.8 & 62 & 0.0 & 18.5 \\
MW90 & 4.6 & 0.2 & 61 & 0.6 & 18.7 \\
MW80 & 3.6 & 0.6 & 59 & 0.0 & 19.0 \\
\hline
\end{tabular}

rotational speed and with windshifter (MW80) provided the largest reduction of ash $(-7.4 \%)$ and moisture $(-3.9 \%)$ and increased the HHV by $9 \%$ (Table 3 ). The fuel mass loss (fine and coarse particles) at the MW80 setting was $48.9 \%$ (Table $2)$. Strong linear correlations $\left(R^{2}=0.93\right)$ were found for fuel mass loss (\% wet basis) and ash content (\%) (Figure 2). Notably, the ash content of the accept fractions and the fuel mass loss for the screen settings M90, M80, and MW100 were very similar (Table 2 and Figure 2).

Fuel Analyses. Mass Fractions of Ash-Forming Elements in Fuels. The dominating elements in all fuels were $\mathrm{Si}, \mathrm{Ca}, \mathrm{K}$, and $\mathrm{Al}$. The amount of main ash-forming elements $(\mathrm{mg} / \mathrm{kg}$ d.b.) decreased by mechanical screening (Table 4). Irrespective of the screening procedure, the reduction in $\mathrm{Si}$ and $\mathrm{Al}$ was higher than the other ash-forming elements, which indicates that screening removed extrinsic ash minerals more efficiently. However, when extrinsic $\mathrm{Si}$ was removed by screening, the relative concentration of primarily $\mathrm{Ca}$ and $\mathrm{K}$ increased proportionally (Table 4). Overall, the fuel analysis indicates that besides the reduction of $\mathrm{Si}$ and an increase in $\mathrm{Ca}$ and $\mathrm{K}$, only minor changes in fuel ash composition were achieved by screening. 


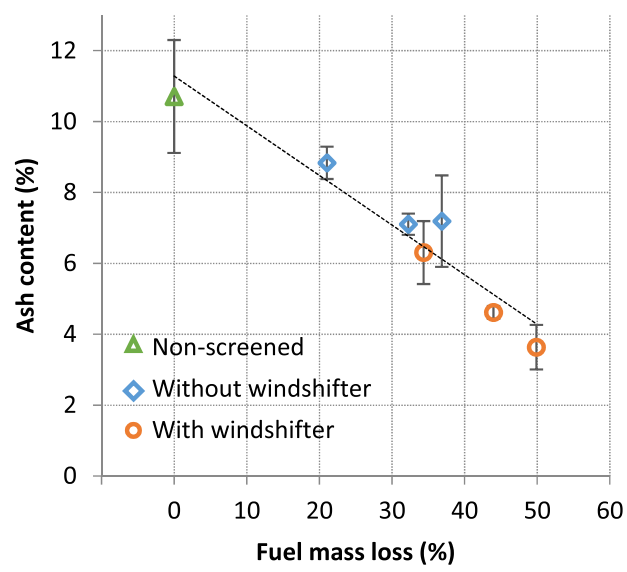

Figure 2. Quantified effects of different mechanical screening settings showing ash content of the accept fraction vs fuel mass loss (\%) during screening. The dotted line illustrates the correlation between the measured parameters. Error bars show $95 \%$ confidence intervals of the mean.

From the fuels' ash composition (in wt \% of oxides), the prediction of slagging tendencies for biomass fuels that are poor in $\mathrm{P}$ can be presented in a compositional diagram consisting of $\mathrm{K}_{2} \mathrm{O}+\mathrm{Na}_{2} \mathrm{O}, \mathrm{CaO}+\mathrm{MgO}$, and $\mathrm{SiO}_{2}$ (Figure 3). ${ }^{40}$ The consolidation of $\mathrm{K}$ and $\mathrm{Na}$ in the ternary diagram is based on the assumption that, in the combustion of lignocellulosic biomass, $\mathrm{Na}$ content is generally low and can be assumed to have similar behavior as $\mathrm{K}$, and thus, the concentrations of $\mathrm{K}$ and $\mathrm{Na}$ can be combined. The same approximation can be made for $\mathrm{Ca}$ and $\mathrm{Mg}$. By interpretation of the compositional diagram, it is shown that all fuel assortments have a composition resulting in higher slagging potential (black-colored area $=$ major slagging tendency). The ash composition of M100, M90, M80, and MW100 did not change considerably compared to the non-screened material. The Si content was efficiently reduced at the MW80 and MW90 screening settings, resulting in a relative increase in both $\mathrm{K}$ and $\mathrm{Ca}$ and $\mathrm{a}$ displacement to the left in the compositional diagram (Figure 3). However, all fuels remain in the higher slagging region. Consequently, the ash-melting

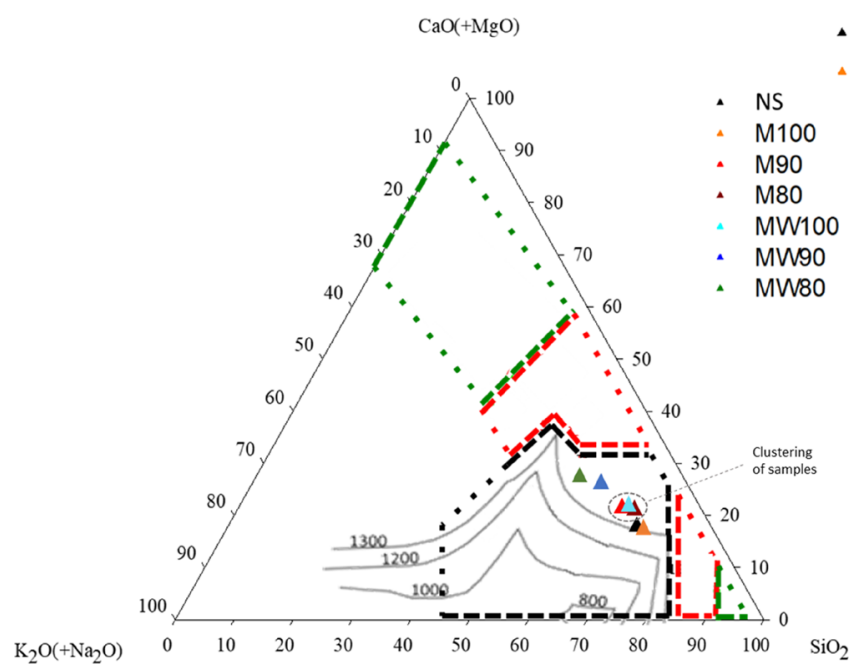

Figure 3. Fuel ash compositions of accept fractions and the nonscreened material before combustion in the $\mathrm{SiO}_{2}-\mathrm{K}_{2} \mathrm{O}\left(\mathrm{Na}_{2} \mathrm{O}\right)-$ $\mathrm{CaO}(\mathrm{MgO})$ system. The colored areas correspond to green $=$ no/low slagging tendency, red = moderate slagging tendency, and black = major slagging tendency. Reprinted (adapted) with permission from ref 40. Copyright 2017 American Chemical Society.

behavior of the fuels cannot be expected to change by screening.

Macro-TGA Combustion and Chemical Composition of Residual Ashes. The effects of different mechanical screening procedures on the fuel's combustion properties were investigated by macro-TGA experiments performed in a singlepellet reactor. From the visual observations and the logged mass loss, no difference in combustion behavior was found between the fuels, except for M100 that seemingly had a faster char conversion. Data on average devolatilization time and char conversion time for each fuel are shown in Table 5. The mass loss behavior is illustrated in the Supporting Information (Figure S1). As expected, the amounts of residual ash after combustion at $850{ }^{\circ} \mathrm{C}$ were between 11 and $34 \%$ lower than the ash contents obtained by standard ash content determination (Table 3), and this is a well-known phenomenon. $^{41}$

Table 4. Content of Main Ash-Forming Elements in the Forest Fuels and the Relative Composition of the Ash-Forming Elements in wt \% of Total Ash

\begin{tabular}{|c|c|c|c|c|c|c|c|c|}
\hline element & unit & non-screened & M100 & M90 & M80 & MW100 & MW90 & MW80 \\
\hline \multirow[t]{2}{*}{$\mathrm{K}$} & mg/kg d.b. & 4930 & 3890 & 3980 & 3160 & 2580 & 3230 & 2610 \\
\hline & wt $\%$ of ash & 9.8 & 9.6 & 10.9 & 9.5 & 9.3 & 13.0 & 14.5 \\
\hline \multirow[t]{2}{*}{$\mathrm{Na}$} & $\mathrm{mg} / \mathrm{kg}$ d.b. & 2040 & 1500 & 1350 & 1220 & 1070 & 692 & 726 \\
\hline & wt $\%$ of ash & 4.1 & 3.7 & 3.7 & 3.7 & 3.8 & 2.8 & 4.0 \\
\hline \multirow[t]{2}{*}{$\mathrm{Ca}$} & $\mathrm{mg} / \mathrm{kg}$ d.b. & 8030 & 6530 & 6890 & 6180 & 5610 & 5600 & 4360 \\
\hline & wt $\%$ of ash & 16.0 & 16.2 & 18.8 & 18.7 & 20.1 & 24.2 & 24.2 \\
\hline \multirow[t]{2}{*}{$\mathrm{Mg}$} & mg/kg d.b. & 1180 & 971 & 852 & 935 & 819 & 692 & 508 \\
\hline & wt $\%$ of ash & 2.4 & 2.4 & 2.3 & 2.8 & 2.9 & 2.8 & 2.8 \\
\hline \multirow[t]{2}{*}{$\mathrm{Fe}$} & $\mathrm{mg} / \mathrm{kg} \mathrm{d.b.}$ & 2360 & 1940 & 1780 & 1800 & 1130 & 1110 & 799 \\
\hline & wt $\%$ of ash & 4.7 & 4.8 & 4.9 & 5.4 & 4.1 & 4.5 & 4.4 \\
\hline \multirow[t]{2}{*}{$\mathrm{Al}$} & $\mathrm{mg} / \mathrm{kg}$ d.b. & 6210 & 4590 & 4050 & 3380 & 2840 & 2260 & 2000 \\
\hline & wt $\%$ of ash & 12.4 & 11.4 & 11.1 & 10.2 & 10.2 & 9.1 & 11.1 \\
\hline \multirow[t]{2}{*}{$\mathrm{Si}$} & mg/kg d.b. & 24,600 & 20,300 & 17,000 & 15,800 & 13,200 & 10,100 & 6530 \\
\hline & wt $\%$ of ash & 49.2 & 50.3 & 46.6 & 47.7 & 47.5 & 41.0 & 36.3 \\
\hline \multirow[t]{2}{*}{$\mathrm{P}$} & $\mathrm{mg} / \mathrm{kg} \mathrm{d.b.}$ & 718 & 636 & 625 & 654 & 586 & 645 & 472 \\
\hline & wt $\%$ of ash & 1.4 & 1.6 & 1.7 & 2.0 & 2.1 & 2.6 & 2.6 \\
\hline
\end{tabular}


Table 5. Devolatilization and Char Conversion during the Combustion of Different Fuels ${ }^{a}$

\begin{tabular}{|c|c|c|c|c|c|c|}
\hline \multirow[b]{2}{*}{$\begin{array}{l}\text { screen } \\
\text { setting }\end{array}$} & \multicolumn{2}{|c|}{ devolatilization } & \multicolumn{2}{|c|}{ char conversion } & \multicolumn{2}{|c|}{ ash content } \\
\hline & $\begin{array}{l}\text { average time } \\
(\mathrm{s})\end{array}$ & std & $\begin{array}{l}\text { average time } \\
(\mathrm{s})\end{array}$ & std & $\begin{array}{c}\text { average } \\
(\%)\end{array}$ & std \\
\hline $\begin{array}{l}\text { non- } \\
\text { screened }\end{array}$ & 57 & 1.2 & 306 & 6.5 & 7.6 & 1.0 \\
\hline M100 & 56 & 1.4 & 278 & 6.6 & 7.1 & 1.3 \\
\hline M90 & 56 & 0.9 & 309 & 11.3 & 5.7 & 0.5 \\
\hline M80 & 55 & 1.4 & 296 & 5.9 & 6.4 & 0.6 \\
\hline MW100 & 57 & 0.5 & 301 & 4.8 & 5.1 & 0.5 \\
\hline MW90 & 56 & 1.5 & 296 & 7.2 & 3.2 & 0.6 \\
\hline MW80 & 57 & 0.5 & 296 & 4.0 & 2.4 & 0.3 \\
\hline
\end{tabular}

${ }^{a}$ Average values and standard deviations are based on eight replicates.

SEM image analysis of residual ashes from the combusted fractions showed only small morphological differences between samples. The ash samples were dominated by porous particles with unreacted silica grains (quartz). However, low amounts of small melts were found in all samples. Examples of formed slag are visualized in Figure 5. The chemical composition of residual ashes was dominated by $\mathrm{Si}, \mathrm{Ca}, \mathrm{K}$, and $\mathrm{Al}$. Low levels of $\mathrm{Na}, \mathrm{Mg}, \mathrm{Fe}$, and $\mathrm{P}$ were also found (Figure 4). Notably, lower levels of Si were observed for all fuels in the SEM-EDS analysis than in the fuel analysis (Figure 3).

Consequently, the relative concentrations of the other ashforming elements increased, especially for Ca. The ash composition change by screening was a possible decrease in Si content for MW90 and MW80 and a significant increase in $\mathrm{K}$ in MW80. The fuels' heterogeneity is reflected by the high standard deviations in the elemental ash compositions and is most likely derived from the uneven distribution of extrinsic contaminations.

The XRD diffractograms were very similar for all samples. Table 6 presents the ashes' phase composition; no consistent trends could be observed based on the semi-quantitative analysis of relative concentrations. Overall, the crystalline phases were dominated by quartz, feldspars, melilite, and kalsilite $\left(\mathrm{KAlSiO}_{4}\right)$. Phosphorus was found at minor levels as whitlockite $\left(\mathrm{Ca}_{3}\left(\mathrm{PO}_{4}\right)_{2}\right)$ and hydroxyapatite $\left(\mathrm{Ca}_{5}\left(\mathrm{PO}_{4}\right)_{3} \mathrm{OH}\right)$.

\section{DISCUSSION}

The reduction of ash content in the fuel was improved by decreasing the stars' rotation speed in the fine deck and by windshifting (Table 3 ). Windshifting was necessary to obtain an ash content below $5 \%$. The screening had a moderate effect on moisture content and the HHV. The results in Table 3 generally agree with earlier research, suggesting an increased HHV with reduced ash content and moisture content. ${ }^{14,42}$ At the most effective setting (MW80), the ash content was reduced by $66 \%$, and the HHV increased by $9 \%$. However, this quality improvement was connected to a fuel mass loss of $50 \%$ (Figure 2 and Table 2), implying that screening forest fuels with this level of sand and mineral contaminations might not be economically sound. The comparable properties of accepts from the settings M90, M80, and MW100 (Figures 2 and 4) indicate that a lower rotational speed without a windshifter is preferred compared to using an additional windshifting unit. Also, an additional machine adds cost and lowers the capacity.

The ash content $(10.7 \%)$ and the concentration of $\mathrm{Si}$ in the ash $(\sim 50 \%)$ for the non-screened material (Tables 3 and 4 ) are considerably higher compared to what is found in the literature, ${ }^{21,43}$ suggesting that the original material was severely contaminated with soil and sand minerals. However, with standard procedures in the fuel supply chain, long-term storage in the forest, by the forest road, and at the fuel yard, high contents of extrinsic inorganic matter (dust, sand, and gravel) can be expected. The assortment was considered a "standard forest fuel" at the heat and power plant from which the material originated.

The most significant effect of screening on the ash-forming elements was the reduction of $\mathrm{Si}$ and $\mathrm{Al}$, indicating that the screening process effectively removed sand and soil contaminations (quartz and $\mathrm{Al}$ silicates). ${ }^{5}$ However, although the ash content in the fuel decreased for all fuels, the relative concentrations between ash-forming elements in the fuel ash remained relatively unchanged, except for the settings MW90 and MW80, where a higher reduction of Si was obtained. In all fuels, the ash was dominated by $\mathrm{Si}$, and therefore it can be expected that silica-based chemistry will dominate ash transformation reactions. About 80 wt \% of the main ashforming elements in all fuels consisted of $\mathrm{K}(+\mathrm{Na}), \mathrm{Ca}(+\mathrm{Mg})$,

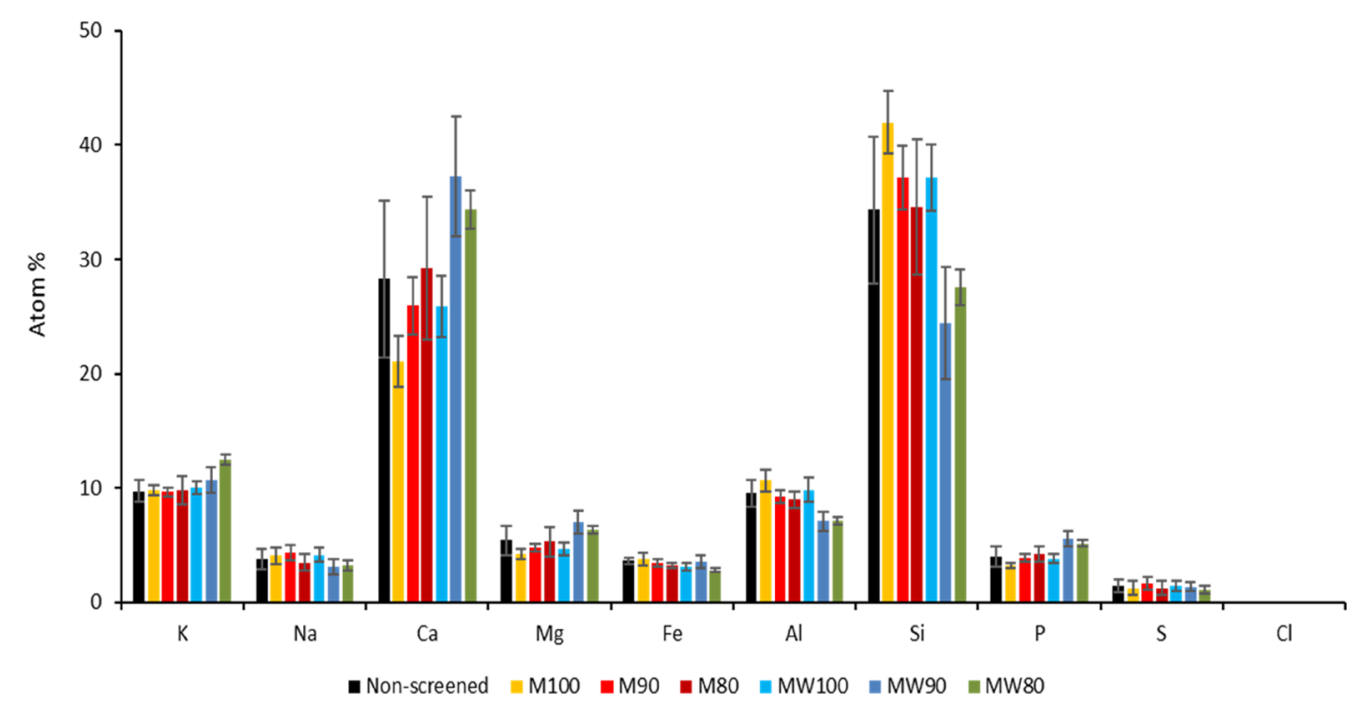

Figure 4. Average elemental composition (SEM-EDS) on the C-and O-free basis of the residual ash samples. 

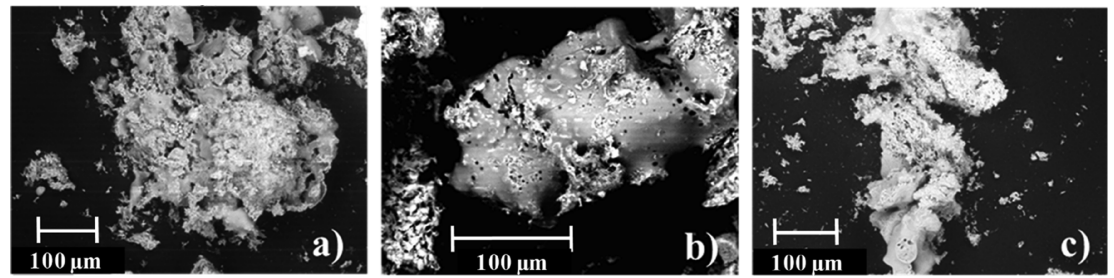

Figure 5. Typical examples of formed slag found in (a) non-screened material, (b) M100 fraction, and (c) MW80 fraction (backscattered electron images from SEM).

Table 6. Semi-Quantitative Analysis Results of Crystalline Phases Identified with XRD ${ }^{a}$

\begin{tabular}{|c|c|c|c|c|c|c|c|}
\hline compound & non-screened & M100 & M90 & M80 & MW100 & MW90 & MW80 \\
\hline $\mathrm{MgO}$ (periclase) & & & & & $*$ & $*$ & \\
\hline $\mathrm{Fe}_{2} \mathrm{O}_{3}$ (hematite) & $*$ & $*$ & $*$ & $*$ & $*$ & $*$ & $*$ \\
\hline $\mathrm{Ca}(\mathrm{OH})_{2}$ (portlandite) & $*$ & $*$ & $*$ & $* *$ & $*$ & $* *$ & $* *$ \\
\hline $\mathrm{SiO}_{2}$ (quartz) & $* *$ & $* * *$ & $* *$ & $* *$ & $* *$ & $* *$ & $* * *$ \\
\hline $\mathrm{CaSiO}_{3}$ (wollastonite) & & & & $*$ & $*$ & & \\
\hline $\mathrm{KAlSiO}_{4}$ (kalsilite) & $* *$ & $* *$ & $* *$ & $*$ & $* *$ & $* *$ & $*$ \\
\hline$(\mathrm{Ca}, \mathrm{Na})_{2}\left(\mathrm{Al}, \mathrm{Mg}, \mathrm{Fe}^{2+}\right)(\mathrm{Al}, \mathrm{Si}) \mathrm{SiO}_{7}$ (melilite) & $* *$ & $* *$ & $* *$ & $* *$ & $* *$ & $* *$ & $* *$ \\
\hline$(\mathrm{Na}, \mathrm{K}, \mathrm{Ca})(\mathrm{Al}, \mathrm{Si}) \mathrm{Si}_{2} \mathrm{O}_{8}$ (feldspar) & $* * *$ & $* * *$ & $* * *$ & $* * *$ & $* * *$ & $* * *$ & $* * *$ \\
\hline $\mathrm{Ca}_{3}\left(\mathrm{PO}_{4}\right)_{2}$ (whitlockite) & $*$ & $* *$ & $*$ & $* *$ & $* *$ & $* *$ & $*$ \\
\hline $\mathrm{Ca}_{5}\left(\mathrm{PO}_{4}\right)_{3} \mathrm{OH}$ (apatite) & $*$ & $*$ & $*$ & $*$ & $*$ & $*$ & \\
\hline
\end{tabular}

and $\mathrm{Si}$, despite ash content reduction. The ash composition of the fuels in this study indicates that available $\mathrm{K}$ and $\mathrm{Ca}$ can react with the dominating $\mathrm{Si}$ and that a fraction of the ash can form low-melting alkali silicates. Increased amounts of $\mathrm{K}$ tend to increase the slagging tendency as low-melting $\mathrm{K}$ silicates may form, whereas increasing $\mathrm{Ca}$ tends to have the opposite effect by the formation of Ca silicates, which have a higher melting temperature. If $\mathrm{K}$ silicates are initially formed, then the $\mathrm{K}$ release to gas phase may be enhanced by $\mathrm{Ca}$ incorporation into the melts, which can lead to an increased risk for fouling and corrosion as more gaseous $\mathrm{K}$ compounds are available to form, e.g., $\mathrm{KCl}^{5,25,27,32,44,45}$

The compositional diagram indicates that ash for all fuels has major slagging tendencies (Figure 3). Worth noting is that the forest fuel material used in this study was severely contaminated. Zeng et al. ${ }^{31}$ performed experiments with less contaminated forest fuel chips (ash content: 1.1-7.4 wt \% d.b.), with less slagging tendencies, and in that case, no slag formation in the bottom ash was expected and found. The main effect of all screening settings in this study was the removal of extrinsic ash-forming elements, dominated by $\mathrm{Si}$. Consequently, the relative concentration of $\mathrm{Si}$ decreased with increasing screening efficiency, i.e., in particular for MW90 and MW80. Although a change in the ash composition was observed for MW90 and MW80, these fuels remained in the higher slagging region. However, extrinsic Si has previously been shown to be less reactive than inherent $\mathrm{Si}^{20,24}$ so with a high content of extrinsic Si from soil contaminants, a slightly lower slagging tendency could be expected than the phase diagram indicates. On the other hand, Näzelius et al. ${ }^{40}$ found sintered ash after combustion of fuels containing contaminants despite their relatively low slagging tendency according to the fraction of fuel ash that forms slag. Lindström et al. ${ }^{4}$ suggested that contaminants might increase the Si concentration in the melt by dissolving into the molten ash.

Despite the relatively low combustion temperature in the TGA furnace (approximately $1000{ }^{\circ} \mathrm{C}$ ), SEM-EDS analysis revealed traces of slag in the ash from the TGA combustion for all fuels. Higher combustion temperatures and longer residence time would have resulted in more severe slagging. However, the temperature reached in these experiments was similar to measured temperatures in a commercially available small-scale boiler (in the range of $700-950{ }^{\circ} \mathrm{C}$ ). ${ }^{31}$ In addition to the slagging temperature, the combustion technology also affects the slagging. Feldmeier et al. $^{46}$ showed that the fraction of the fuel ash that formed slag and the slag formation's severity varied a lot when combusted in different small-scale appliances.

It was expected that the combustion kinetics of the fuels would change as a consequence of screening. Fuels with higher ash content can have a more extended char conversion phase due to the ash layer limiting char burnout, resulting in residual carbon. ${ }^{47}$ In this study, no apparent differences in combustion behavior (devolatilization and char conversion) between the fuels were found (Table 5).

The only significant effect of the screening operations according to SEM-EDS analyses was a, for the MW80 fuel, slightly increased concentration of $\mathrm{K}$ in the ash after combustion, which is in keeping with the small changes in relative concentrations between ash-forming elements in the ash (Table 4). The decrease in $\mathrm{Si}$ and the corresponding increase in Ca, especially for MW90 and MW80 (compared to data in Figure 4), could not be identified due to high variability in the residual ash elemental composition SEM-EDS analyses. Extrinsic contaminants, i.e., Si grains, are comparatively large and can show inhomogeneous spatial distribution, making SEM-EDS area analysis sampling challenging, which might explain the low concentrations of detected $\mathrm{Si}$.

According to the XRD analysis (Table 6), all samples showed apparent sand mineral contamination (quartz and feldspars). The feldspars identified are most likely a mixture of albite $\left(\mathrm{NaAlSi}_{3} \mathrm{O}_{8}\right)$ and microcline $\left(\mathrm{KAlSi}_{3} \mathrm{O}_{8}\right)$, which both are considered common contaminations, ${ }^{4}$ although it should be mentioned that the exact composition of the feldspars could not be determined in this analysis. However, they have 
common properties from an ash-chemistry point of view and could, therefore, be described as feldspar phases. Besides the sand mineral contamination silicates, two other silicates, melilite $\left((\mathrm{Ca}, \mathrm{Na})_{2}\left(\mathrm{Al}, \mathrm{Mg}, \mathrm{Fe}^{2+}\right)(\mathrm{Al}, \mathrm{Si}) \mathrm{SiO}_{7}\right)$ and kalsilite $\left(\mathrm{KAlSiO}_{4}\right)$, were identified in high levels. The identified melilite might originate as mineral contamination but has also been identified as a combustion product.

In contrast, the identified kalsilite is a common combustion product. ${ }^{4,5}$ The melilite found contained high levels of $\mathrm{Ca}$ and $\mathrm{Mg}$, suggesting melilite preferably in the form of akermanite $\left(\mathrm{MgCa}_{2} \mathrm{Si}_{2} \mathrm{O}_{7}\right)$. Portlandite was identified in all samples; however, portlandite is usually not a primary combustion product. It is formed from lime $(\mathrm{CaO})$ or calcite $\left(\mathrm{CaCO}_{3}\right)$, reacting with ambient moisture after combustion. Regarding fuel compositions and combustion conditions, lime $(\mathrm{CaO})$ or calcite $\left(\mathrm{CaCO}_{3}\right)$ was expected to be found in the samples. Overall, the crystalline phase analysis shows only small deviations between the analyzed samples, which is in good agreement with the compositional diagram and the elemental compositional analysis from the SEM.

\section{CONCLUSIONS}

Mechanical screening of severely contaminated forest fuel chips efficiently reduced ash and fines in the accept fraction. The HHV increased slightly, but the moisture content was not affected. However, the fuel mass loss for the different screening operations was significant at a magnitude of $20-50 \%$. Mechanical screening of the studied fuel did not improve the relative concentration of the main ash-forming elements to a great extent since the removal of $\mathrm{Si}$ resulted in a relative increase in both $\mathrm{K}$ and $\mathrm{Ca}$. Combustion characteristics and ash-melting behavior can thus be expected to remain unchanged and based on the elemental composition, the fuels remain in the higher slagging region. Combustion studies in laboratory scale and analysis of the residual ashes showed no significant deviation between screened and non-screened fuels. However, a reduction in ash content and fine particles can reduce operational problems in small and sensitive combustion units.

\section{ASSOCIATED CONTENT}

\section{SI Supporting Information}

The Supporting Information is available free of charge at https://pubs.acs.org/doi/10.1021/acs.energyfuels.0c03196.

Mass loss behavior for logging residue pellets during combustion in macro-TGA (PDF)

\section{AUTHOR INFORMATION}

\section{Corresponding Author}

Sylvia H. Larsson - Department of Forest Biomaterials and Technology, Swedish University of Agricultural Sciences, S90183 Umeå, Sweden; 이이.org/0000-0001-56473630; Email: sylvia.larsson@slu.se

\section{Authors}

Marjan Bozaghian Bäckman - Department of Forest Biomaterials and Technology, Swedish University of Agricultural Sciences, S-901 83 Umeå, Sweden

Anna Strandberg - Department of Forest Biomaterials and Technology, Swedish University of Agricultural Sciences, S90183 Umeå, Sweden; Department of Applied Physics and Electronics, Thermochemical Energy Conversion Lab, Umeå
University, S-901 87 Umeå, Sweden; 이잉.org/00000003-0895-3474

Mikael Thyrel - Department of Forest Biomaterials and Technology, Swedish University of Agricultural Sciences, S90183 Umeå, Sweden

Dan Bergström - Department of Forest Biomaterials and Technology, Swedish University of Agricultural Sciences, S90183 Umeå, Sweden

Complete contact information is available at:

https://pubs.acs.org/10.1021/acs.energyfuels.0c03196

\section{Notes}

The authors declare no competing financial interest.

\section{ACKNOWLEDGMENTS}

We thank Bio4Energy, a strategic research environment appointed by the Swedish government, and the Swedish University of Agricultural Sciences for supporting this work. The authors would like to thank Dr. Markus Carlborg at TEClab, Umeå University for evaluating the XRD diffractograms. This research was partly done in the BioHub project financed by the Botnia-Atlantica program under the 569 European Regional Development Fund.

\section{REFERENCES}

(1) Christiansen, L. Skogsstatistisk årsbok, 2014. In Author Jonköping; Swedish Forest Agency: Sweden: 2014.

(2) Routa, J.; Asikainen, A.; Björheden, R.; Laitila, J.; Röser, D. Forest energy procurement: state of the art in Finland and Sweden. Wiley Interdiscip. Rev.: Energy Environ. 2013, 2, 602-613.

(3) Swedish Energy Agency Produktion, import och export av oförädlade trädbränslen. http://pxexternal.energimyndigheten.se/ pxweb/sv/Produktion, import och export av oförädlade trädbränslen / - /EN0122_3.px/?rxid=15989e6d-2e0c-485a-96d4eefd08e 86850

(4) Lindström, E.; Larsson, S. H.; Boström, D.; Öhman, M. Slagging characteristics during combustion of woody biomass pellets made from a range of different forestry assortments. Energy Fuels 2010, 24, $3456-3461$

(5) Lindström, E.; Öhman, M.; Backman, R.; Boström, D. Influence of Sand Contamination on Slag Formation during Combustion of Wood Derived Fuels. Energy Fuels 2008, 22, 2216-2220.

(6) Spinelli, R.; Ivorra, L.; Magagnotti, N.; Picchi, G. Performance of a mobile mechanical screen to improve the commercial quality of wood chips for energy. Bioresour. Technol. 2011, 102, 7366-7370.

(7) Kuptz, D.; Hartmann, H. The effect of raw material and machine setting on chipping performance and fuel quality-a German case study. Int. J. For. Eng. 2015, 26, 60-70.

(8) Moskalik, T.; Gendek, A. Production of Chips from Logging Residues and Their Quality for Energy: A Review of European Literature. Forests 2019, 10, 262.

(9) Van Loo, S.; Koppejan, J. The handbook of biomass combustion and co-firing; Earthscan: 2012.

(10) ISO, E. 17225-1. Solid Biofuels-Fuel Specifications and ClassesPart 1: General Requirements; ISO: Geneva, Switzerland 2014.

(11) Dukes, C. C.; Baker, S. A.; Greene, W. D. In-wood grinding and screening of forest residues for biomass feedstock applications. Biomass Bioenergy 2013, 54, 18-26.

(12) Greene, W. D.; Cutshall, J. B.; Dukes, C. C.; Baker, S. A. Improving woody biomass feedstock logistics by reducing ash and moisture content. BioEnergy Research 2014, 7, 816-823.

(13) Huber, C.; Kroisleitner, H.; Stampfer, K. Performance of a mobile star screen to improve woodchip quality of forest residues. Forests 2017, 8, 171.

(14) Kuptz, D.; Schreiber, K.; Schulmeyer, F.; Lesche, S.; Zeng, T.; Ahrens, F.; Zelinski, V.; Schön, C.; Pollex, A.; Borchert, H.; Lenz, V.; 
Loewen, A.; Nelles, M.; Hartmann, H. Evaluation of combined screening and drying steps for the improvement of the fuel quality of forest residue wood chips-results from six case studies. Biomass Conversion and Biorefinery 2019, 9, 83-98.

(15) Jensen, P. D.; Mattsson, J. E.; Kofman, P. D.; Klausner, A. Tendency of wood fuels from whole trees, logging residues and roundwood to bridge over openings. Biomass Bioenergy 2004, 26, $107-113$.

(16) Rackl, M.; Günthner, W. A. Experimental investigation on the influence of different grades of wood chips on screw feeding performance. Biomass Bioenergy 2016, 88, 106-115.

(17) Jenkins, B. M.; Baxter, L. L.; Miles, T. R., Jr.; Miles, T. R. Combustion properties of biomass. Fuel Process. Technol. 1998, 54, $17-46$.

(18) Oser, M.; Nussbaumer, T.; Schweizer, B.; Mohr, M.; Figi, R. Influences on aerosol formation in an automatic wood furnace. Aerosols Biomass Combust. 2001, 32, 59-64.

(19) Johansson, L. S.; Tullin, C.; Leckner, B.; Sjövall, P. Particle emissions from biomass combustion in small combustors. Biomass Bioenergy 2003, 25, 435-446.

(20) Boström, D.; Skoglund, N.; Grimm, A.; Boman, C.; Öhman, M.; Broström, M.; Backman, R. Ash transformation chemistry during combustion of biomass. Energy Fuels 2011, 26, 85-93.

(21) Werkelin, J.; Skrifvars, B.-J.; Hupa, M. Ash-forming elements in four Scandinavian wood species. Part 1: Summer harvest. Biomass Bioenergy 2005, 29, 451-466.

(22) Vassilev, S. V.; Baxter, D.; Andersen, L. K.; Vassileva, C. G. An overview of the chemical composition of biomass. Fuel 2010, 89, 913-933.

(23) Fernandez-Lacruz, R.; Bergström, D. Windrowing and fuel-chip quality of residual forest biomasses in northern Sweden. International Journal of Forest Engineering 2017, 28, 186-197.

(24) Zevenhoven, M.; Yrjas, P.; Skrifvars, B.-J.; Hupa, M. Characterization of Ash-Forming Matter in Various Solid Fuels by Selective Leaching and Its Implications for Fluidized-Bed Combustion. Energy Fuels 2012, 26, 6366-6386.

(25) Baxter, L. L.; Miles, T. R.; Miles, T. R., Jr.; Jenkins, B. M.; Milne, T.; Dayton, D.; Bryers, R. W.; Oden, L. L. The behavior of inorganic material in biomass-fired power boilers: field and laboratory experiences. Fuel Process. Technol. 1998, 54, 47-78.

(26) Nielsen, H. P.; Frandsen, F. J.; Dam-Johansen, K.; Baxter, L. L. The implications of chlorine-associated corrosion on the operation of biomass-fired boilers. Prog. Energy Combust. Sci. 2000, 26, 283-298.

(27) Novaković, A.; van Lith, S. C.; Frandsen, F. J.; Jensen, P. A.; Holgersen, L. B. Release of potassium from the systems $\mathrm{K}-\mathrm{Ca}-\mathrm{Si}$ and $\mathrm{K}-\mathrm{Ca}-\mathrm{P}$. Energy Fuels 2009, 23, 3423-3428.

(28) Fagerström, J.; Steinvall, E.; Boström, D.; Boman, C. Alkali transformation during single pellet combustion of soft wood and wheat straw. Fuel Process. Technol. 2016, 143, 204-212.

(29) Niu, Y.; Tan, H.; Hui, S. Ash-related issues during biomass combustion: Alkali-induced slagging, silicate melt-induced slagging (ash fusion), agglomeration, corrosion, ash utilization, and related countermeasures. Prog. Energy Combust. Sci. 2016, 52, 1-61.

(30) Rebbling, A.; Sundberg, P.; Fagerström, J.; Carlborg, M.; Tullin, C.; Boström, D.; Öhman, M.; Boman, C.; Skoglund, N. Demonstrating Fuel Design To Reduce Particulate Emissions and Control Slagging in Industrial-Scale Grate Combustion of Woody Biomass. Energy Fuels 2020, 34, 2574-2583.

(31) Zeng, T.; Kuptz, D.; Schreiber, K.; Schön, C.; Schulmeyer, F.; Zelinski, V.; Pollex, A.; Borchert, H.; Loewen, A.; Hartmann, H.; Lenz, V.; Nelles, M. Impact of adhering soil and other extraneous impurities on the combustion and emission behavior of forest residue wood chips in an automatically stoked small-scale boiler. Biomass Conversion and Biorefinery 2019, 9, 99-116.

(32) Öhman, M.; Boström, D.; Nordin, A.; Hedman, H. Effect of kaolin and limestone addition on slag formation during combustion of wood fuels. Energy Fuels 2004, 18, 1370-1376.

(33) Steenari, B.-M.; Lundberg, A.; Pettersson, H.; Wilewska-Bien, M.; Andersson, D. Investigation of ash sintering during combustion of agricultural residues and the effect of additives. Energy Fuels 2009, 23, $5655-5662$

(34) Boström, D.; Grimm, A.; Boman, C.; Björnbom, E.; Öhman, M. Influence of kaolin and calcite additives on ash transformations in small-scale combustion of oat. Energy Fuels 2009, 23, 5184-5190.

(35) Rebbling, A.; Näzelius, I.-L.; Piotrowska, P.; Skoglund, N.; Boman, C.; Boström, D.; Öhman, M. Waste Gypsum Board and AshRelated Problems during Combustion of Biomass. 2. Fixed Bed. Energy Fuels 2016, 10705.

(36) Gilbe, C.; Öhman, M.; Lindström, E.; Boström, D.; Backman, R.; Samuelsson, R.; Burvall, J. Slagging characteristics during residential combustion of biomass pellets. Energy Fuels 2008, 22, 3536-3543.

(37) Nielsen, N. P. K.; Gardner, D. J.; Poulsen, T.; Felby, C. Importance of temperature, moisture content, and species for the conversion process of wood residues into fuel pellets. Wood Fiber Sci. 2009, 41, 414-425.

(38) Strandberg, A.; Thyrel, M.; Skoglund, N.; Lestander, T. A.; Broström, M.; Backman, R. Biomass pellet combustion: Cavities and ash formation characterized by synchrotron X-ray micro-tomography. Fuel Process. Technol. 2018, 176, 211-220.

(39) Kabekkodu, S. PDF-4+ 2019 (Database); International Centre for Diffraction Data: Newtown Square, PA, USA, 2019.

(40) Näzelius, I.-L.; Boström, D.; Rebbling, A.; Boman, C.; Öhman, M. Fuel Indices for Estimation of Slagging of Phosphorus-Poor Biomass in Fixed Bed Combustion. Energy Fuels 2017, 31, 904-915.

(41) Thy, P.; Jenkins, B. M.; Grundvig, S.; Shiraki, R.; Lesher, C. High temperature elemental losses and mineralogical changes in common biomass ashes. Fuel 2006, 85, 783-795.

(42) Lestander, T. A.; Rhén, C. Multivariate NIR spectroscopy models for moisture, ash and calorific content in biofuels using biorthogonal partial least squares regression. Analyst 2005, 130, 11821189.

(43) Vassilev, S. V.; Vassileva, C. G.; Song, Y.-C.; Li, W.-Y.; Feng, J. Ash contents and ash-forming elements of biomass and their significance for solid biofuel combustion. Fuel 2017, 208, 377-409.

(44) Thy, P.; Lesher, C. E.; Jenkins, B. M. Experimental determination of high-temperature elemental losses from biomass slag. Fuel 2000, 79, 693-700.

(45) Bozaghian, M.; Rebbling, A.; Larsson, S. H.; Thyrel, M.; Xiong, S.; Skoglund, N. Combustion characteristics of straw stored with $\mathrm{CaCO} 3$ in bubbling fluidized bed using quartz and olivine as bed materials. Appl. Energy 2018, 212, 1400-1408.

(46) Feldmeier, S.; Wopienka, E.; Schwarz, M.; Schön, C.; Pfeifer, C. Applicability of Fuel Indexes for Small-Scale Biomass Combustion Technologies, Part 1: Slag Formation. Energy Fuels 2019, 33, 1096910977.

(47) Chen, C.; Kojima, T. Single char particle combustion at moderate temperature: effects of ash. Fuel Process. Technol. 1996, 47, 215-232. 